\title{
Oppsiktsvekkende lav forekomst av Helicobacter pylori hos barn
}

Helicobacter pylori finnes hos færre barn i Bodø enn i resten av verden, mens de voksne i Bodø og Sørreisa er på vesteuropeisk nivå.

Halvparten av verdens befolkning er infisert med Helicobacter pylori i magesekken. Denne infeksjonen er hovedårsaken til kronisk magekatarr og magesår. Bakterien er assosiert med utvikling av kreft i magesekken, særlig i Øst-Asia. Forekomsten av bakterien hos folk har de siste tiår blitt kraftig redusert $\mathrm{i}$ industrialiserte land, mens den fortsatt er så høy som $90 \%$ i enkelte utviklingsland.

I mitt doktorarbeid har vi kartlagt forekomsten av bakterien hos folk i Bodø sentrum og i Sørreisa kommune. Vi ønsket å finne ut når og hvordan magesårsbakterien smittes, og om den henger sammen med funksjonelle tarmplager.
Vi fant at bakterien ikke bare smittes i barndommen, men også i ungdomstiden. Kun $0,6 \%$ av barn under 12 år var smittet. Vi fant ingen sammenheng mellom forekomst av bakterien og funksjonelle tarmplager.

Vårt forskningsarbeid gjør at teorien om at smitten overføres fra mor til barn i tidlig barnealder kan utfordres. Ingen definitive alternative forklaringer ble påvist, men smitte kan være knyttet til bruk av utedo, kontakt med husdyr og drikkevann fra private brønner i barndommen.

\section{Ragnar Kåre Breckan}

rbreckan@online.no

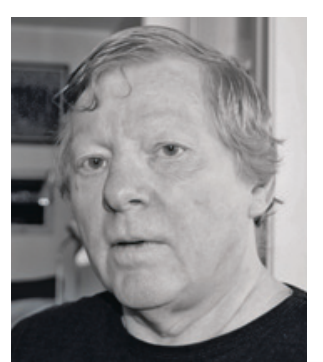

Ragnar Kåre Breckan. Foto: Silje Paulsen Breckan

\section{Disputas}

Cand.med. Ragnar Kåre Breckan disputerte for ph.d.-graden ved Universitetet i Tromsø 9. juni 2016 på Nordlandssykehuset i Bodø. Tittelen på avhandlingen er The All-Age Prevalence of Helicobacter pylori Infection and Potential Transmission Routes. A Population-Based Study.

\section{Akuttmedisin i ein distriktskommune}

\section{Akuttmedisinske hendingar i lokalsamfunnet skjer relativt hyppig og har ei stor variasjonsbreidd. Det er vanskeleg å predikere alvorsgraden i dei ved den første meldinga.}

Trass $i$ at det har vore stor merksemd rundt faglege og organisatoriske forhold ved dei prehospitale tenestene, har det ikkje vore gjort detaljerte studier av akuttmedisinske hendingar i lokalsamfunnet.

Vi har i denne avhandlinga studert to aspekt ved akuttmedisin i lokalsamfunnet, sett frå fastlegeteneste og legevakt, og samarbeidet mellom kommunetenestenivået og ambulansetenesta. Dei to delstudiane som avhandlinga består av vart gjort i øykommunen Austevoll.

I den første studien registrerte vi prospektivt all akuttmedisinsk aktivitet i kommunen i toårsperioden 2005-07. Dei deltakande legane og ambulansepersonellet fylte ut omfattande registreringsskjema for kvar hending. Dei viktigaste funna var ein akuttmedisinsk hendingsfrekvens på $2,7 \%$ av populasjonen per år, at det vart registrert 62 ulike diagnosar, og at legen sin vurdering av det kliniske situasjonsalvoret vart nedgradert i $42 \%$ av hendingane og oppgradert i $11 \%$.
I den andre studien vart det opplært akutthjelparar i to utkantar av Austevoll til innsats ved hjartestans og mistenkt hjarteinfarkt mens ein venta på lege og ambulanseteneste. Studien gjekk over fem år, og hovudføremålet var å studere om gruppeorganiseringa av akutthjelparar kunne vedlikehaldast over desse fem åra. Gruppene fungerte heile femårsperioden, men veikskapar ved gruppefungeringa kunne konstaterast.

Hovudkonklusjonar frå den første studien er at legen er ein viktig ressurs framme hos pasienten ved dei akuttmedisinske situasjonane, i lag med ambulansetenesta. Frå den andre studien var ein hovudkonklusjon at akutthjelpargrupper ikkje kan vere ein sjølvstendig del av akuttberedskapen i kommunane.

\section{Sverre Rørtveit}

sverre.rortveit@aknett.net

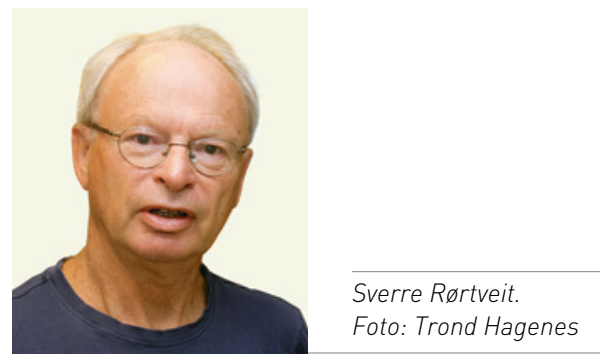

Disputas

Sverre Rørtveit disputerte for ph.d.-graden ved Universitetet i Bergen 30. september 2016. Tittelen på avhandlinga er Akuttmedisin i ein distriktskommune. 